\title{
Halomonas Venusta Mediated Detoxification and Biotransformation of Selenite Into Selenium Nanoparticles Exhibiting Various Biomedical Applications
}

\section{Diviya Chandrakant Vaigankar}

Laboratory of Bacterial Genetics and Environmental Biotechnology, Department of Microbiology, Goa University, Taleigao Plateau, Goa, India

Santosh Kumar Dubey ( $\nabla$ santoshdubey.gu@gmail.com )

Banaras Hindu University

\section{Sajiya Yusuf Mujawar}

Laboratory of Bacterial Genetics and Environmental Biotechnology, Department of Microbiology, Goa University, Taleigao Plateau, Goa, India

\section{Ajeet Kumar Mohanty}

ICMR-National Institute of Malarial Research, Field Unit, DHS Building, Campal, Panaji, Goa, India

\section{Research}

Keywords: Anti-biofilm, Anti-oxidant, Chemotherapeutic agent, Mosquito-larvicidal, Selenium nanoparticles

Posted Date: July 28th, 2020

DOI: https://doi.org/10.21203/rs.3.rs-45336/v1

License: (c) (i) This work is licensed under a Creative Commons Attribution 4.0 International License. Read Full License 


\section{Abstract}

Marine environment is in constant threat due to anthropogenic activities which are involved in disturbing the aquatic flora and fauna due to accumulation of toxic metals and metalloids. The current study involves the use of microbial remediation strategy for reduction of toxic sodium selenite $\left(\mathrm{Na}_{2} \mathrm{SeO}_{3}\right)$ into less toxic elemental $\mathrm{Se}\left(\mathrm{Se}^{0}\right)$ with concurrent synthesis of Se nanoparticles (SeNPs) possessing several biomedical potential. Selenite reducing bacterial strain isolated from Mandovi estuary of Goa, India was identified as Halomonas venusta based on 16S rRNA gene sequence analysis and designated as strain GUSDM4. It's maximum tolerance level for $\mathrm{Na}_{2} \mathrm{SeO}_{3}$ was $100 \mathrm{mM}$. The 2, 3-diaminonaphthalene based spectroscopic analysis clearly demonstrated $93 \%$ reduction of $4 \mathrm{mM} \mathrm{Na}_{2} \mathrm{SeO}_{3}$ to $\mathrm{Se}^{0}$ during late stationary growth phase of Halomonas venusta. Biosynthesis of SeNPs commenced within $4 \mathrm{~h}$ during log phase which was clearly evident from red colour in the growth medium and a characteristic peak at $265 \mathrm{~nm}$ revealed by UV-Vis spectrophotometry. The intracellular synthesis of SeNPs was confirmed by transmission electron microscopy (TEM) of these bacterial cells. Characterization of SeNPs by X-ray crystallography, TEM and energy dispersive X-ray analysis clearly demonstrated spherical SeNPs of 20-80 $\mathrm{nm}$ diameter with hexagonal crystal lattice. These SeNPs at $50 \mu \mathrm{g} / \mathrm{mL}$ exhibited $90 \%$ free radical scavenging activity and also demonstrated anti-biofilm activity at $20 \mu \mathrm{g} / \mathrm{mL}$ against common human pathogens which was evident by SEM analysis. These SeNPs interestingly revealed excellent dosedependent and selective anti-proliferative activity against A549 cancer cell line and mosquito larvicidal activity against Aedes aegypti, Culex quinquefasciatus and Anopheles stephensi. Therefore, these studies have demonstrated amazing potential of marine bacterium, Halomonas venusta in bioremediation along with biosynthesis of SeNPs and their applications as free radical scavenger, anti-biofilm, chemotherapeutic and larvicidal agents which is the first report of its kind.

\section{Introduction}

The extensive industrialization and various anthropogenic activities have significantly contaminated the estuarine environment with several metalloid pollutants viz. arsenic, tellurium and selenium over past several decades disturbing its ecological balance. Environmental protection from toxic metal and metalloid pollutants released in the aquatic and terrestrial environment requires specific strategies to protect and restore these contaminated environments. Therefore, extensive broadening of research spectrum for bioremediation of these pollutants by diverse group of microorganisms is of great concern for environmental microbiologists.

Selenium (Se) is widely distributed metalloid of Group XVI of periodic table, sharing structural and chemical similarities with sulphur and tellurium. It occurs in the environment as inorganic, unstable selenide $\left(\mathrm{Se}^{2}\right)$, water soluble selenite $\left(\mathrm{SeO}_{3}{ }^{2-}\right)$, selenate $\left(\mathrm{SeO}_{4}{ }^{2-}\right)$ and water insoluble elemental selenium $\left(\mathrm{Se}^{0}\right)$. Organic forms include selenocysteine and selenomethionine. Interestingly Se is a significant trace 
element in all domains of life, and it forms an important structural component of various selenoproteins viz. thioredoxin reductase and glutathione peroxidase (Allan et al. 1999). It is commonly referred as 'double-edged sword' since in human beings the nutritional dose of Se (i.e. 200-400 $\mu \mathrm{g} /$ day) boosts immunity and also promotes cell death (Arthur et al. 2003; Zeng et al. 2008). Moreover, its deficiency leads to 'Keshan disease' and excess of Se $(<400 \mu \mathrm{g} / \mathrm{mL})$ causes selenosis (Chen 2012; Morris and Crane 2013).

Selenite is introduced into the environment mainly due to weathering of rocks, coal carbonization, seleniferous agricultural drainage, sewage and effluents from various industries viz. glass, plastic, paint, pigments, oil and tanneries (Javed et al. 2015). Selenite contamination of water bodies and apparently drinking water adversely affects human health due to its biomagnification (Ouédraogo et al. 2015). Being highly bioavailable selenite is taken up easily by the majority of plants and animals present in the aquatic environment and ultimately enters the human food chain posing a serious threat to the health of all the components of the food chain. These alarming conditions provoked environmental microbiologists to explore and design biological systems and tools to detoxify and bioremediate selenite from marine polluted sites which are eco-friendly and cost-effective (Higashi et al. 2005; Soda et al. 2012; Eswayah et al. 2016).

Although selenium is toxic to various life forms, microorganisms including bacteria can tolerate and survive very high concentrations of selenite without any adverse effects on their cellular metabolism (Ghosh et al. 2008). Reduction of selenite to elemental selenium and methylation to volatile forms such as dimethyl selenide are widely studied mechanisms involved in selenite biotransformation (Ranjard et al. 2002; Hunter and Manter 2009). However, there are very few reports on selenite resistant marine bacteria (Siddique et al. 2006; Narasingarao and Häggblom 2007; Mishra et al. 2011; Rauschenbach et al. 2011; Forootanfar et al. 2014; Srivastava et al. 2014; Samant et al. 2018).

Selenite bioreduction to insoluble elemental selenium by bacteria can be nanostructured since the process of bioreduction and nanoparticle synthesis takes place simultaneously (Tan et al. 2016). Therefore, the use of estuarine bacteria for simultaneous selenite reduction and biosynthesis of nanomaterials will certainly be highly favourable, environmental friendly and economically viable. Since other chemical and physical processes involve environmentally hazardous techniques along with the use of toxic materials and radiations (Velmurugan et al. 2014; Presentato et al. 2018).

Selenium in nano-dimensions has gained tremendous attention and are high in demand due to its extensive applications in electronics, agriculture, food, feed and environmental bioremediation along with a special emphasis in the field of medicine due to its crucial biological role even at low concentration (Shirsat et al. 2015). The specificity, selectivity, bioavailability and low toxicity of SeNPs make them one of the most promising candidate to be used for biomedical applications. The antioxidant activity of SeNPs has gained tremendous attention worldwide; on the other hand, developing an antioxidant with low cost and toxicity remains a challenging task. Thus, development of a novel nontoxic, nano-Se antioxidant is desirable and imperative. 
Se is also known as anti-microbial and anti-biofilm agent against diverse microbial pathogens. Due to the increasing drug resistance worldwide, scientists are now looking out for alternative antimicrobials to treat microbial infections. The problem is severe while handling biofilm-associated microbial infections. Under such circumstance's development of a novel, antibiofilm material in nano-forms is mandatory. SeNPs have also been studied widely for their anti-cancer activity against various cancer cell lines (Chen et al. 2008; Zheng et al. 2011; Luo et al. 2012). Several concerns and complications in current anti-cancer therapy including non-specificity, non-selectivity, rapid drug deactivation, reduced pharmacokinetics, restricted bio-distribution, side effects and cost-effectiveness of anti-cancer drugs have severely hampered the effectiveness of treatments. However, SeNPs address all the above concerns making them ideal and most demanding novel anti-cancer drug.

It's worth mentioning that every year 70 million people are affected due to mosquito-borne diseases globally, among which 4 million is Indian population (Ghosh et al. 2012). Mosquito acts as an important vector for most of the fatal and life-threatening vector borne diseases viz. malaria, dengue, yellow fever, filariasis, zika and chikungunya. These diseases pose a serious threat to both developing and developed countries across the globe due to their re-emergence and tendency to spread outside the known geographic regions causing epidemics. Nanoparticle-based approach to control this vector would be very promising due to its specificity. In the present study, we have reported Halomonas venusta mediated detoxification and biotransformation of selenite into selenium nanoparticles exhibiting anti-oxidant, antibiofilm, anticancer, and mosquito larvicidal activity.

\section{Materials And Methods}

\section{Isolation of selenite reducing estuarine bacteria}

The surface water sample from Mandovi estuary Goa, India was collected using sterile polycarbonate bottle (Latitude: $15^{0} 30^{\prime} 4.36^{\prime \prime} \mathrm{N}$, Longitude: $73^{\circ} 49^{\prime} 46.17^{\prime \prime} \mathrm{E}$ and temperature $\left.25^{\circ} \mathrm{C}\right)$. Water sample $(1 \mathrm{~mL})$ was added to $50 \mathrm{~mL}$ Zobell Marine Broth (ZMB) supplemented with $0.5 \mathrm{mM}$ sodium selenite $\left(\mathrm{Na}_{2} \mathrm{SeO}_{3}\right)$ and was incubated at $25^{\circ} \mathrm{C} \pm 2$ with constant shaking $(150 \mathrm{rpm})$ for $48 \mathrm{~h}$. Dilution plating of the enriched sample was carried out on Zobell marine agar (ZMA) plates containing $2 \mathrm{mM}$ sodium selenite to isolate selenite reducing bacteria. Discrete brick red coloured colonies obtained were re-streaked on ZMA $(0,2$ $\mathrm{mM} \mathrm{Na}_{2} \mathrm{SeO}_{3}$ ) to screen morphologically distinct selenite reducing bacteria which were considered for further studies.

\section{Determination of Minimum inhibitory concentration (MIC) for selenite}

To determine the MIC for $\mathrm{Na}_{2} \mathrm{SeO}_{3}$, the selected bacterial isolates were spot inoculated on ZMA plates with increasing concentrations of $\mathrm{Na}_{2} \mathrm{SeO}_{3}(0-120 \mathrm{mM})$. The plates were incubated at $25^{\circ} \mathrm{C} \pm 2$ for $24 \mathrm{~h}$ and were checked for appearance of brick red coloured colonies. The minimum concentration at which no visible colonies obtained was designated as MIC. Bacterial isolates with the highest MIC on solid media were selected for determining their MIC in the liquid medium. The strains were grown in the presence of 
various concentrations of sodium selenite $(0-120 \mathrm{mM})$ and were checked for absorbance at $600 \mathrm{~nm}$ after $24 \mathrm{~h}$ of incubation.

\section{Identification of selenite reducing bacterial strain GUSDM4}

DNA extraction of the selenite reducing bacterial strain GUSDM4 was carried out using Dneasy® Blood \& Tissue Kit (Qiagen, Hilden, Germany). Universal eubacterial primers: 27F (5'-

AGAGTTTGATCMTGGCTCAG-3') and 1492R(5'-TACGGYTACCTTGTTACGACTT-3') were used to amplify 16S ribosomal RNA gene (16S rRNA) using Nexus Gradient Mastercycler (Eppendorf, Germany). The PCR amplicon was analysed on $1 \%$ agarose gel followed by purification using Wizard SVGel and PCR clean-up system (Promega, USA). The purified 16S rRNA gene was sequenced at Eurofins Genomics, Bangalore, India followed by BLAST analysis and the DNA sequence was submitted to Genbank (Altschul et al. 1990). The Phylogenetic dendrogram was constructed by the Neighbor-joining method using MEGA 7 software (Tamura et al. 2013).

\section{Selenite uptake by bacterial strain GUSDM4}

Time course study of selenite uptake was done using a modified spectrophotometric method as described by Watkinson (1996). Briefly, H. venusta GUSDM4 was grown in the presence of 2 and $4 \mathrm{mM}$ $\mathrm{Na}_{2} \mathrm{SeO}_{3}$ and every $4 \mathrm{~h}, 0.5 \mathrm{~mL}$ aliquot was centrifuged at $9727 \mathrm{X} \mathrm{g}$ for $10 \mathrm{~min}$. The supernatant $(100 \mu \mathrm{L})$ was used to determine the selenite content. Appropriate controls such as un-inoculated medium with $\mathrm{Na}_{2} \mathrm{SeO}_{3}$ and inoculated medium without metal were kept and processed under similar conditions. For selenite estimation, $0.1 \mathrm{M} \mathrm{HCl}(5 \mathrm{~mL}), 0.1 \mathrm{M} \mathrm{NaF}(0.25 \mathrm{~mL})$ and $1 \mathrm{M}$ disodium oxalate $(0.25 \mathrm{~mL})$ were added and mixed in a test tube. Subsequently, $0.25 \mathrm{~mL}$ culture supernatant, $1.25 \mathrm{~mL}$ of $0.1 \% 2,3 \mathrm{DAN}$ (2,3-diaminonaphthalene) was added, mixed and incubated at $60^{\circ} \mathrm{C}$ for $15 \mathrm{~min}$. The above mixture was cooled at room temperature and $3 \mathrm{~mL}$ of cyclohexane was added to extract selenium - 2,3 DAN complex with vigorous shaking. The solution was then centrifuged at $3000 \mathrm{Xg}$ for $12 \mathrm{~min}$ and absorbance at 377 $\mathrm{nm}$ of the organic phase was determined using UV-Vis spectrophotometer (Shimadzu -1601, Japan). The experiments were performed in triplicates and the standard error was determined.

\section{Biosynthesis and localization of SeNPs by Halomonas venusta strain GUSDM4}

The bacterial strain GUSDM4 was inoculated in ZMB supplemented with $2 \mathrm{mM} \mathrm{Na}_{2} \mathrm{SeO}_{3}$, incubated at 25 ${ }^{\circ} \mathrm{C} \pm 2$ at $150 \mathrm{rpm}$ for $24 \mathrm{~h}$ and observed for colour change. Un-inoculated medium and previously grown culture supernatant with $2 \mathrm{mM}$ of $\mathrm{Na}_{2} \mathrm{SeO}_{3}$ under similar conditions were kept as controls. The selenite reducing strain of $H$. venusta was grown without and with $4 \mathrm{mM} \mathrm{Na}_{2} \mathrm{SeO}_{3}$. The cells were harvested at $6225 \mathrm{Xg}$, followed by washing in $0.1 \mathrm{M}$ phosphate buffered saline (PBS, $\mathrm{pH} 7.4$ ) and were fixed with $2 \%$ para-formaldehyde and $2.5 \%$ glutaraldehyde prepared in PBS for $4 \mathrm{~h}$ at $4{ }^{\circ} \mathrm{C}$. The supernatant obtained after centrifugation was discarded and 0.1 M PBS was added. The samples were sectioned and analysed using TEM (Moragani 268D, Fei Electron Optics, USA).

\section{Optimization and time course study of SeNPs biosynthesis}


Optimization of SeNPs biosynthesis was carried out under different growth conditions viz. pH: 5, 6, 7, 8, 9 and 10; temperature: $18,22,25,28,30,35,37$ and $40{ }^{\circ} \mathrm{C}$; sodium selenite concentration: $1,2,3,4,5$ and 6 $\mathrm{mM}$. The culture was inoculated in ZMB flasks with varying $\mathrm{pH}$, temperature and sodium selenite concentrations respectively. The nanoparticle biosynthesis was monitored at $265 \mathrm{~nm}$ using UV-Vis spectrophotometer which is characteristic for elemental selenium. Time course study for the biosynthesis of SeNPs was also carried out under optimized conditions. The SeNPs were obtained by the protocol described by Vaigankar et al. (2018).

\section{Characterization of biosynthesized nanoparticles}

Biosynthesized SeNPs were suspended in methanol: chloroform $(2: 1 \mathrm{v} / \mathrm{v})$ and analysed for their characteristic optical properties by scanning between 190 to $800 \mathrm{~nm}$ using UV-Vis spectrophotometer (Shimadzu-2450, Japan). X-ray diffraction pattern for biosynthesized SeNPs was obtained using X-ray diffractometer (Rigaku Miniflex). The Scherrer's equation was used to calculate the crystal size of the nanoparticles: where $D$ is the mean grain size, $k$ is constant, $\lambda$ is the $X$-ray wavelength for CuKa radiation, $\beta$ is the FWHM of the diffraction peak in radians and $\theta$ is the Braggs angle. The TEM analysis of the SeNPs was carried out to determine the morphology of the nanoparticles. SeNPs powder was dispersed in methanol and mounted on a carbon-coated copper TEM grid (Philips, model- CM200). The size of the SeNPs was calculated using Image $\mathrm{J}$ software. Energy dispersive $\mathrm{X}$-ray analysis was also carried out to determine the elemental composition of the biogenic nanoparticles. SeNPs were coated with a thin film of carbon and analysed for energy dispersive X-ray analysis using a scanning electron microscope along with EDS (JSM 5800 LV, model-JOEL, Japan).

\section{Applications of biogenic SeNPs}

\section{Anti-oxidant activity}

DPPH (1,1-diphenyl-2-picryllhydrazly) free radical scavenging activity of biogenic SeNPs was investigated using a method described by Turlo et al. (2010) with minor modifications. In the presence of antioxidant purple DPPH changes into yellow stable compound and hydrogen donating capacity of antioxidant determines the extent of reaction (Niki 2010). Different concentrations of biogenic SeNPs were mixed with $1 \mathrm{~mL}$ of freshly prepared $0.2 \mathrm{mM} \mathrm{DPPH}$. These tubes were incubated in the dark for $30 \mathrm{~min}$ and absorbance of the samples was recorded at $570 \mathrm{~nm}$ spectroscopically using ascorbic acid as a standard and methanol as blank. The \% free radical scavenging activity is expressed as follows:

\section{$\%$ scavenging activity}

$=[($ Control absorbance $570 \mathrm{~nm}$

- Sample absorbance $570 \mathrm{~nm}) /$ Control absorbance $570 \mathrm{~nm}] \times 100$

\section{Anti-biofilm potential of SeNPs}


The anti-biofilm activity of biogenic SeNPs against potential human pathogens procured from Goa Medical College, Goa, India viz. Streptococcus pyogenes, Staphylococcus aureus, Klebsiella pneumoniae and Escherichia coli was studied using modified crystal violet assay in a 96 well sterile polystyrene microtiter plate as described previously (Vaigankar et al. 2018). Percent antibiofilm was calculated using the following formula:

\section{$\%$ Anti - biofilm activity}

\section{$=[($ Absorbance of control \\ - absorbance of the sample)/(absorbance of control)] \\ $\times 100$}

where Absorbance of control corresponds to the bacterial cells grown in nutrient broth without NPs. The anti-biofilm assay was carried out in triplicate and the standard deviation was determined. To further confirm this SEM analysis of the bacterial pathogens grown in the presence of $(0,20,25$ and $50 \mu \mathrm{g} / \mathrm{mL}$ SeNPs) were carried out as per the protocol described in Mujawar et al. (2019).

\section{Anti-cancer activity (MTT assay)}

Biogenic SeNPs were evaluated for their cytotoxicity against cancer cells by MTT (3-(4, 5- dimethylthiazol2-yl) -2, 5-diphenyltetrazolium bromide) assay. The dye is reduced by metabolically active human cells due to the action of various dehydrogenase enzymes to pink formazan dye. The adenocarcinomic human alveolar basal epithelial and normal human bronchial epithelial cell lines were used for this study. The cell lines were cultured in Dulbecco's modified Eagle medium with high glucose (DMEM-HG, DMEM-F12) supplemented with 10\% Foetal Bovine Serum (FBS). The cells cultured in T-25 flasks were trypsinized and aspirated into $5 \mathrm{~mL}$ centrifuge tubes. Subsequently, the cell pellet was obtained by harvesting cells at $300 \mathrm{Xg}$ and the cell suspension exhibiting a cell count of $2 \times 10^{4}$ was used for the assay. The $200 \mu \mathrm{L}$ cell suspension was added to a 96 well microtitre plate and the plates were incubated in $5 \% \mathrm{CO}_{2}$ incubator at $37^{\circ} \mathrm{C}$ for $24 \mathrm{~h}$. The cells were incubated with different concentrations of SeNPs for $24 \mathrm{~h}$, followed by addition of MTT reagent (10\%) for $4 \mathrm{~h}$. The media was aspirated without disturbing the formazan crystals formed. Consequently, $100 \mu \mathrm{L}$ of DMSO was added to the plate and absorbance at $570 \mathrm{~nm}$ and $630 \mathrm{~nm}$ was measured using UV-Visible spectrophotometer. Sodium selenite and positive control with cisplatin was also evaluated for their cytotoxicity. The experiment was carried out in triplicates and cell viability relative to unexposed cells (control) was calculated as follows:

$\%$ cell viability $=[($ A test $) /($ A control $)] \times 100$ 
Where $\left(A_{\text {test }}\right)$ is absorbance of the cells treated with SeNPs and $\left(A_{\text {control }}\right)$ is absorbance of the cells without SeNPs treatment.

\section{Larvicidal activity of biogenic SeNPs}

\section{Source of mosquito immatures}

The larvae of Anopheles stephensi, Culex quinquefasciatus and Aedes aegypti were obtained from ICMRNational Institute of Malaria Research, Field Unit, Goa, insectary. The cyclic colonies of these mosquito species were maintained at a temperature of $27 \pm 2{ }^{\circ} \mathrm{C}$ with a relative humidity of $70 \pm 5 \%$ and a photoperiod: scotoperiod of 12:12 h (light: dark). Healthy $3^{\text {rd }}$ instar larvae were used to conduct the bioassay.

\section{Bioassay}

All the three larvae of Anopheles stephensi, Culex quinquefasciatus and Aedes aegypti were used to carry out preliminary bioassay. SeNPs were dissolved in methanol and dilutions were made to attain an appropriate range of dosage. Third instar larvae (25) were transferred to autoclaved plastic containers in $250 \mathrm{~mL}$ of distilled water. These were exposed to various concentrations of SeNPs ranging from 10 to $100 \mathrm{ppm}$ for 24 and $48 \mathrm{~h}$ along with methanol control without addition of NPs suspension. After 24 and $48 \mathrm{~h}$ post-treatment, the number of dead larvae was counted and percent mortality was calculated for each time interval. Abbott's formula was applied to calculate corrected mortality if the control mortality (\%) was between 5 and 20. Probit analysis with SPSS PASW 18.0 was used to determine LC $_{50}$, mean and standard errors. Abbott's formula for calculating corrected mortality is as follows:

\section{$\%$ Mortality $=[(\%$ mortality in the experiment $)$ \\ - $((\%$ mortality in the control $)) / 100-(\%$ mortality in the control $)]$ \\ $\times 100$}

\section{Results And Discussion}

\section{Isolation of selenite reducing estuarine bacteria and it's MIC for selenite}

Morphologically distinct 50 discrete brick red bacterial colonies were obtained after plating the samples on ZMA with $2 \mathrm{mM} \mathrm{Na}_{2} \mathrm{SeO}_{3}$ which were considered for further studies (Supplementary Fig. 1). These selected bacterial isolates did not show any brick red pigmentation upon streaking on ZMA plates without $\mathrm{Na}_{2} \mathrm{SeO}_{3}$ (Supplementary Fig. 2). The Mandovi estuary of Goa is contaminated with various metals and metalloids including selenium due to numerous anthropogenic and industrial activities such as shipping, tourism, mining and construction. It has already been reported that various bacterial isolates from Mandovi estuary possess resistance as well as cross-resistance to iron, manganese, cobalt, copper, zinc, 
lead, chromium, mercury, tributyltin and selenite (Khanolkar et al. 2015; Sunitha et al. 2015; Srivastava and Kowshik 2016; Naik and Dubey 2017; Samant et al. 2018).

Out of fifty, 20 bacterial colonies exhibiting MIC greater than $100 \mathrm{mM} \mathrm{Na}_{2} \mathrm{SeO}_{3}$ were selected for further studies. Estuarine bacterial strain GUSDM4 showing highest MIC of $101 \mathrm{mM}$ in liquid medium for $\mathrm{Na}_{2} \mathrm{SeO}_{3}$ was selected for further characterization. Selenite reducing strain GUSDM4 showed exceptionally highest MIC of $101 \mathrm{mM}$ for $\mathrm{Na}_{2} \mathrm{SeO}_{3}$ as compared to previously reported strains of bacteria. For instance, Idiomarina sp. isolated from the banks of Mandovi estuary, Goa, India showed a MIC of 10 $\mathrm{mM}$ for selenite (Srivastava and Kowshik 2016) which is 10 times lower than the present study.

\section{Identification of selenite reducing bacterial strain GUSDM4}

The bacterial strain GUSDM4 was found to be Gram-negative, motile, rod-shaped, catalase, nitrate and oxidase positive aerobic bacteria. 16S rRNA gene sequencing and sequence comparison against GenBank database using NCBI-BLAST search, strain GUSDM4 was identified as Halomonas venusta (accession number: MG430411). The dendrogram analysis revealed phylogenetic relatedness with other species of Halomonas (Fig. 1).

Strain GUSDM4 was identified as Halomonas venusta. Interestingly, members belonging to family Halomonadaceae are characterized by high salt tolerance $(5-25 \% \mathrm{NaCl})$ and survival at low to high temperatures $\left(4-40^{\circ} \mathrm{C}\right)$. These characteristics make it a remarkable candidate for selenite bioremediation in various habitats ranging from estuaries to saline lakes and oceans. There are very few reports on selenite reduction by genus Halomonas and this is the first detailed study on selenite reduction by Halomonas venusta isolated from Mandovi estuary showing the highest level of selenite resistance.

\section{Selenite uptake studies using bacterial strain GUSDM4}

Selenite uptake by Halomonas venusta strain GUSDM4 grown in ZMB with 2 and $4 \mathrm{mM} \mathrm{Na}_{2} \mathrm{SeO}_{3}$ was observed during the early log phase of growth $(2 \mathrm{~h})$ with a steady increase during the mid-log phase. At mid log phase ( $26 \mathrm{~h}$ ), a $50 \%$ reduction of selenite was observed. However, $93 \%$ and $96 \%$ utilization of selenite was achieved at the end of the stationary growth phase for $4 \mathrm{mM}$ and $2 \mathrm{mM}$ respectively (Fig. 2). The uptake studies also revealed significant ability of the strain GUSDM4 to reduce $93 \%$ of selenite to elemental selenium during the late stationary phase $(58 \mathrm{~h})$ of growth. It's worth mentioning that the previous study on Rhodospirillum rubrum showed selenite reduction at the commencement of the stationary phase which is non-favaourable and also contradictory to the current study (Kessi et al. 1999). Thus, further strengthening its potential to be used for various biotechnological applications including nanoparticle biosynthesis.

\section{Biosynthesis and localization of SeNPs by Halomonas venusta strain GUSDM4}


Selenite reduction to elemental Se using strain GUSDM4 was evident by the colour change in the medium from yellow to brick red in the flask with $2 \mathrm{mM} \mathrm{Na}_{2} \mathrm{SeO}_{3}$. Whereas, control flask without $\mathrm{Na}_{2} \mathrm{SeO}_{3}$ and cell free supernatant with $2 \mathrm{mM} \mathrm{Na}_{2} \mathrm{SeO}_{3}$ did not show any brick red colouration thus, confirming intracellular synthesis of SeNPs (Supplementary Fig. 3). It was found that in the presence of selenite H. Venusta strain GUSDM4 demonstrated electron dense deposits throughout the periplasm which was distinctly absent in the control cells. Moreover, intracellular spherical deposits of SeNPs were also visible within the bacterial periplasm (Fig. 3 a, b). Halomonas venusta strain GUSDM4 successfully synthesized Se nanoparticles intracellularly which was initiated within $4 \mathrm{~h}$ of the growth phase and was confirmed from a characteristic at $265 \mathrm{~nm}$ using UV-Vis spectrophotometry.

The intracellular periplasmic nanoparticle synthesis was further confirmed using TEM analysis which exclusively demonstrated biosynthesis in exposed bacterial cells. Previously, halophilic bacteria namely Bacillus selenitireducens, Selenihalanaerobacter shriftii, Sulfospirillum barnesii, Bacillus megaterium, Bacillus cereus and Idiomarina sp. PR58-8 have been reported for SeNPs biosynthesis (Dhanjal and Cameotra 2010; Forootanfar et al. 2014; Srivastava and Kowshik 2016; Samant et al. 2018). Moreover, similar observation of periplasmic spherical nano-Se biosynthesis has also been reported in strain Se-1-1 belonging to Pseudoalteromonas sp. (Rathgeber et al. 2002). We have reported for the first time intracellular biosynthesis of SeNPs by the marine bacterium Halomonas venusta.

\section{Optimization and time course study of SeNPs biosynthesis}

Optimization of SeNPs biosynthesis with respect to $\mathrm{pH}$, temperature and $\mathrm{Na}_{2} \mathrm{SeO}_{3}$ was studied during intracellular synthesis. The optimum $\mathrm{pH}$, temperature and $\mathrm{Na}_{2} \mathrm{SeO}_{3}$ for $\mathrm{SeNPs}$ biosynthesis were $7,25^{\circ} \mathrm{C}$ and $4 \mathrm{mM}$ respectively (Fig. 4 a, b, c). Time course study of SeNPs further revealed that the biosynthesis was initiated during early log phase (i.e. $4 \mathrm{~h}$ ) which was evident from the colour change in the media and a distinctly sharp peak at $265 \mathrm{~nm}$. Biosynthesis of SeNPs was time-dependent reaching maxima at $34 \mathrm{~h}$ of bacterial growth (Fig. 4d).

It was interesting to note that the estuarine strain GUSDM4 could synthesize SeNPs within a broad range of temperature (i.e. 18 to $40^{\circ} \mathrm{C}$ ) and pH (i.e. 5 to 10). Although MTC for the strain GUSDM4 was recorded to be $100 \mathrm{mM}$ the nanoparticle synthesis was not carried at such a high concentration since it is a wellknown fact that nanoparticles at high salt concentrations tend to aggregate forming particles with a larger diameter which is undesirable (Stoeva et al. 2002). Earlier studies on SeNPs biosynthesis by marine Bacillus sp. MSh-1 demonstrated that biosynthesis was initiated after $14 \mathrm{~h}$ of incubation (Forootanfar et al. 2014). Therefore, our strain GUSDM4 is very efficient in the biosynthesis of SeNPs.

\section{Characterization of biosynthesized nanoparticles}

The UV-Vis spectrophotometry analysis clearly revealed an absorbance peak of brick red colloidal solution at $265 \mathrm{~nm}$ due to surface plasmon resonance indicating the presence of SeNPs (Fig. 5a). The XRD analysis revealed characteristic Bragg's peaks at 23.46, 29.76 and 43.72, corresponding to [100], [101] and [110] lattices of hexagonal Se respectively (ICDD-card no.06-0362). The average size of the 
crystal domain was calculated to be $37.27 \mathrm{~nm}$ (Fig. 5b). TEM micrographs of SeNPs revealed spherical morphology with size ranging from 20 to $80 \mathrm{~nm}$ (Fig. 5d). The EDAX analysis demonstrated the absorption peaks at 1.5, 11.2 and $12.5 \mathrm{KeV}$ thus, further reiterating presence of elemental Se (Fig. 5c).

The characterization of SeNPs using XRD, TEM and EDAX analysis confirmed the presence of pure spherical SeNPs exhibiting hexagonal crystal lattice with a diameter in the range of 20-80 nm. Previously, Zooglea ramigera has been reported to biosynthesize spherical SeNPs with diameter ranging from 30 to $130 \mathrm{~nm}$ (Srivastava and Mukhopadhyay 2013). Similarly, in another study size distribution of 200-400 $\mathrm{nm}$ was observed using the halophilic bacteria $B$. selenitriducens, $S$. shriftii and $S$. barnesii (Oremland et al. 2007). Size of NPs plays a major role in determining the functions of nanoparticles, smaller the size greater are the chances of enhancing its functionality and efficiency.

\section{Applications of biogenic SeNPs}

\section{Anti-oxidant activity}

Biogenic SeNPs exhibited excellent dose-dependent anti-oxidant activity. An increasing percent free radical scavenging activity with increasing concentrations of SeNPs was recorded (Fig. 6). For instance, the percent scavenging activity at $25 \mu \mathrm{g} / \mathrm{mL}$ of biogenic SeNPs was recorded $50 \%$ while $90 \%$ at 50 $\mu \mathrm{g} / \mathrm{mL}$.

The biogenic SeNPs interestingly demonstrated $90 \%$ free radical scavenging activity at $50 \mu \mathrm{g} / \mathrm{mL}$. Higher antioxidant activity of SeNPs is mainly due to the presence of seleno-enzymes viz. glutathione peroxidase and thioredoxin reductase, which are known to play a pivotal role in preventing the free radicals. Previous findings on anti-oxidant activity by biogenic SeNPs also showed a similar dosedependent trend but at higher concentrations i.e. 100 to $1000 \mu \mathrm{g} / \mathrm{mL}$. In this case, the percent scavenging activity at $100 \mu \mathrm{g} / \mathrm{mL}$ was $80 \%$, while at $1000 \mu \mathrm{g} / \mathrm{mL}$ the activity was $100 \%$ (Ramya et al. 2015). However, the current study demonstrated approximately $90 \%$ free radical scavenging activity at $50 \mu \mathrm{g} / \mathrm{mL}$ SeNPs which is highly significant. Moreover, another study demonstrated $23.1 \pm 3.4 \%$ free radical scavenging activity at $200 \mu \mathrm{g} / \mathrm{mL}$ SeNPs (Forootanfar et al. 2014). Differences in the \% free radical scavenging activity may be attributed to the difference in the size of biosynthesized nanoparticles with the fact that smaller particles are known to exhibit greater free radical scavenging activity as compared to larger aggregates (Torres et al. 2012).

\section{Anti-biofilm activity}

SeNPs demonstrated dose-dependent anti-biofilm activity against Gram-positive and Gram-negative bacterial pathogens (Fig. 7a). Highest anti-biofilm activity was recorded against $K$. pneumonia at 20 (39.45\%), $25(55.89 \%)$ and $50(90.96 \%) \mu \mathrm{g} / \mathrm{mL}$. This was followed by E. coli in which 38.56, 48.58 and $78.26 \%$ inhibition of biofilm was observed. Whereas, in Gram-positive, S. aureus 18.89, 35.89 and 60.89 \% inhibition was observed while in S. pyogenes inhibition was 9.58, 18.56 and $55.89 \%$ at 20, 25 and 50 $\mu \mathrm{g} / \mathrm{mL}$ respectively. Further, SEM images clearly revealed dislodging of bacterial biofilms along with 
morphological alterations in the form of surface depressions with increasing concentrations of SeNPs (Fig. 7b). SeNPs also exhibited excellent anti-biofilm activity against four potential biofilm forming bacterial strains. The highest anti-biofilm activity was observed against $K$. pneumoniae followed by $E$. coli, S. aureus and S. pyogenes. Previously, a similar \% reduction of $S$. aureus, P. aeruginosa and $P$. Mirabilis biofilms were reported (Shakibaie et al. 2015). These results also corroborated with the SEM analysis demonstrating the dislodging of bacterial biofilms. This opens a new arena of applications for SeNPs as coating agents in medical and health-related devices in order to prevent bacterial infections caused by biofilm forming bacteria. Likewise, these SeNPs may also have promising applications in industrial sectors as potential tools to combat biofouling. In addition, they can also serve as excellent candidates to eradicate biofilm formation in sewage tanks and other sewerage systems.

\section{Anti-cancer activity}

Dose-dependent toxicity of SeNPs towards cancer cells was very much evident. SeNPs were very effective in inhibiting the A549 cell lines at concentrations as low as $10 \mu \mathrm{g} / \mathrm{mL}$ while at $70 \mu \mathrm{g} / \mathrm{mL}$ complete mortality was observed (Fig. 8a). Interestingly, SeNPs were ineffective against normal human bronchial epithelial cells (BEAS-2B) as no mortality was observed. We have also clearly observed effect of SeNPs on cancer cell line using electron microscopy (Fig. 8 b, c, d, e). The untreated A549 cells were highly dense, confluent and abundant. However, after treatment with SeNPs large cells have circularized and shrunk showing decrease in density and adherence of cells.

Biogenic SeNPs exhibited excellent dose-dependent anti-cell proliferative characteristics at low doses. At $70 \mu \mathrm{g} / \mathrm{mL}$ complete mortality of A549 human lung cancer cell line was observed. Although, selenium compounds viz. selenite, selenate, selenomethionine, selenocysteine and methyl-selenocysteine are known to be anti-carcinogenic the concentrations at which these compounds are effective is very high and toxic (Zhang et al. 2007; Seng and Tiekink 2012). SeNPs have attracted considerable attention due to its exceptional biological potential and reduced toxicity (Luo et al. 2012). Biogenic SeNPs have been reported for its anticancer activity and are found to be effective against various cancer cell lines viz. MCF7/breast adenocarcinoma, MDA-MB-231/human breast carcinoma, A375/ human melanoma, LNcaP/prostrate, HK-2/human kidney, HepG2/liver hepatocellular carcinoma cell lines and HeLa/human cervical carcinoma (Chen et al. 2008; Kong et al. 2011; Zheng et al. 2011; Luo et al. 2012; Ramya et al. 2015). The high specificity of SeNPs to the cancer cells may be due to the difference in anti-oxidant enzyme regulations which are over-expressed in case of cancer cells (Fang et al. 2005). Morphological alterations in SeNPs treated cells were also eveident of its anti-cell proliferative activity. Similar morphological alterations in Hela cells and MDA-MB-231 cells have been reported earlier in the presence of selenium nanoparticles by Luo et al. (2012). Keeping in view the nonspecificity and adverse effects of present chemotherapeutic treatments, use of these highly specific Se-nano-therapeutics would be the best alternative.

\section{Mosquito larvicidal activity}


SeNPs exhibited larvicidal activity against all three tested spp. of mosquito as evident from $\mathrm{LC}_{50}$ and $\mathrm{LC}_{90}$ values of SeNPs against laboratory-reared larvae of An. stephensi, $C x$. quinquefasciatus and $A e$. Aegypti (Table 1). Among all the mosquito spp. tested, highest larval mortality (after 24 and $48 \mathrm{~h}$ of posttreatment) was recorded for $C x$. quinquefasciatus with $\mathrm{LC}_{50}$ of 29.92 and $24.8 \mathrm{ppm}$ respectively, trailed by Ae. aegypti with $\mathrm{LC}_{50}$ of 50.37 and $44.5 \mathrm{ppm}$ and An. stephensi with $\mathrm{LC}_{50}$ of 59.18 and $58.41 \mathrm{ppm}$ respectively.

SeNPs also revealed the dose dependent larvicidal potential against mosquito spp. SeNPs were most effective against $C x$. quinquefasciatus followed by Ae. Aegypti and An. stephensi. Previously, SeNPs synthesized from leaf extract of $C$. dentata was reported to exhibit $\mathrm{LC}_{50}$ of $240.714 \mathrm{ppm}, 104.13 \mathrm{ppm}$ and 99.602 ppm for An. stephensi, Ae. Aegypti and Cx. quinquefasciatus respectively (Sowndarya et al. 2017). However, the reported doses have $\mathrm{LC}_{50}$ values at much higher concentrations than the current study, which is almost 4.1, 2.34 and 4 fold higher for An. stephensi, Ae. Aegypti and Cx. quinquefasciatus respectively. The microscopic images of the test and control larvae revealed that SeNPs are showing toxicity once the nanoparticles are internalised by the larvae (Supplementary Fig. 4).

The vector control strategies mainly target adults or larvae and largely involve the use of chemical insecticides. The repetitive use of these hazardous insecticides foster various complications which mainly include development of insecticide-resistance, natural biological control system disruption, outburst of other insects and undesired effect on non-target insect spp. (Yang et al. 2002). The advantages associated with larval control include low mortalities and effective coverage due to behavioural responses of immature mosquito. Nanoparticle-based approach can be most desired due to its specificity and effectiveness at low concentrations. Thus, the use of biogenic SeNPs as a mosquito larvicidal agent would be much favourable.

Table 1: Larvicidal activity of biogenic SeNPs against An. stephensi, Ae. Aegypti and Cx. quinquefasciatus. 


\begin{tabular}{|c|c|c|c|c|}
\hline & $24 \mathrm{~h}$ & & $48 \mathrm{~h}$ & \\
\hline Mosquito spp. & $\begin{array}{l}\mathrm{LC}_{50} \\
\text { (lower and upper } \\
\text { limit) }\end{array}$ & $\begin{array}{l}\mathrm{LC}_{90} \\
\text { (lower and upper } \\
\text { limit) }\end{array}$ & $\begin{array}{l}\mathrm{LC}_{50} \\
\text { (lower and upper } \\
\text { limit) }\end{array}$ & $\begin{array}{l}\text { LC }_{90} \\
\text { (lower and upper } \\
\text { limit) }\end{array}$ \\
\hline $\begin{array}{l}\text { Anopheles } \\
\text { stephensi }\end{array}$ & $\begin{array}{l}59.189 \\
(44.753-78.282)\end{array}$ & $\begin{array}{l}141.163 \\
(106.734- \\
186.699)\end{array}$ & $\begin{array}{l}\mathbf{5 8 . 4 1 0} \\
(44.156-77.265)\end{array}$ & $\begin{array}{l}140.500 \\
(106.500- \\
185.856)\end{array}$ \\
\hline Aedes aegypti & $\begin{array}{l}\mathbf{5 0 . 3 7 8} \\
(35.081-72.345)\end{array}$ & $\begin{array}{l}159.076 \\
(110.773- \\
228.441)\end{array}$ & $\begin{array}{l}44.506 \\
(32.004-61.892)\end{array}$ & $\begin{array}{l}129.488 \\
(93.114-180.079)\end{array}$ \\
\hline $\begin{array}{l}\text { Culex } \\
\text { quinquefasciatus }\end{array}$ & $\begin{array}{l}29.925 \\
(20.838-42.977)\end{array}$ & $\begin{array}{l}87.734 \\
(61.091-125.997)\end{array}$ & $\begin{array}{l}24.800 \\
(16.678-36.8790)\end{array}$ & $\begin{array}{l}\mathbf{8 2 . 3 8 3} \\
(558.401- \\
122.505)\end{array}$ \\
\hline
\end{tabular}

\section{Conclusions}

Selenite reducing Halomonas venusta strain GUSDM4 isolated from Mandovi estuary of Goa, India showed MIC of $101 \mathrm{mM}$ for $\mathrm{Na}_{2} \mathrm{SeO}_{3}$. This bacterial strain demonstrated a $93 \%$ reduction of selenite to elemental selenium during the late stationary phase $(58 \mathrm{~h})$ of growth. It showed intracellular periplasmic SeNPs synthesis within $4 \mathrm{~h}$ of the growth phase and was confirmed from a characteristic peak at $265 \mathrm{~nm}$ using UV-Vis spectrophotometry. XRD, TEM, and EDAX analysis further confirmed the presence of pure spherical SeNPs exhibiting hexagonal crystal lattice with a diameter in the range of 20-80 nm. The biogenic SeNPs interestingly demonstrated $90 \%$ free radical scavenging activity at $50 \mu \mathrm{g} / \mathrm{mL}$ and also exhibited excellent dose dependent anti-cell proliferative characteristics. Additionally these SeNPs also revealed the larvicidal potential against mosquito spp. Thus, a biotechnologically potent estuarine Halomonas venusta strain GUSDM4 can be utilized simultaneously for bioremediation of toxic selenite to elemental selenium and biosynthesis of SeNPs with value added characteristics. In the present investigation, we have reported for the first time biosynthesis of SeNPs using estuarine bacterial strain Halomonas venusta which showed anti-oxidant, anti-cancer and mosquito larvicidal potential.

\section{Abbreviations}

\% ]: Percentage, ${ }^{\circ} \mathrm{C}$ : Degree centigrade, $\mu \mathrm{g}$ : Microgram, $\mu \mathrm{l}$ : Microlitre, 2, 3-DAN: 2, 3-diaminonaphthalene, BLAST: Basic local alignment search tool, DMEM-HG: Dulbecco's modified Eagle medium with high glucose, DPPH: 1,1-diphenyl-2-picryllhydrazly, EDS: Energy dispersive spectroscopy, FBS: Foetal Bovine Serum, h: hour, LC: lethal concentration, MIC: minimum inhibitory concentration,mM: mill molar, MTC: maximum tolerance concentration, MTT: 3-(4, 5- dimethylthiazol-2-yl) -2, 5-diphenyltetrazolium bromide, 
$\mathrm{NaCl}$ : sodium chloride, $\mathrm{Na}_{2} \mathrm{SeO}_{3}$ : sodium selenite, $\mathrm{nm}$ : nanometer, Se: selenium, $\mathrm{Se}^{0}$ : elemental $\mathrm{Se}, \mathrm{Se}^{2}$ : selenide, SEM: Scanning electron microscope, SeNPs: Se nanoparticles, $\mathrm{SeO}_{4}{ }^{2-}$ : selenite, TEM: transmission electron microscope, XRD: X-ray diffraction , ZMA: Zobell marine agar and ZMB: Zobell marine broth.

\section{Declarations}

\section{Acknowledgement}

The authors thank Mr Areef Sardar and Mr Girish Prabhu from CSIR-National Institute of Oceanography, Goa for EDAX and XRD analysis respectively. The authors also acknowledge AlIMS, New Delhi for TEM analysis.

\section{Author's contribution}

DCV has designed, performed and analysed the experiments. She has also prepared the draft of the manuscript. SKD has contributed in experimental designs, verification of the data and critically correcting the manuscript to bring in the final form. SYM has assisted in experimental work and making draft manuscript. AKM, has helped in designing and conducting mosquito larvicidal assays. All authors have read and approved the manuscript.

\section{Funding information}

This work was supported by University Grants Commission, New Delhi as junior research fellow [Ref. no. F/2017-18(SA-III)].

\section{Availability of data and materials}

Not applicable

\section{Ethics approval and consent to participate}

Not applicable

\section{Consent for publication}

Not applicable

\section{Conflict of interest}

The authors have no conflict of interest.

\section{References}


1. Allan CB, Lacourciere GM, Stadtman TC (1999) Responsiveness of selenoproteins to dietary selenium. Ann Rev Nutr 19: 1-16.

2. Altschul SF, Gish W, Miller W, Myers EW, Lipman DJ (1999) Basic local alignment search tool. J Mol Biol 215:403-410.

3. Arthur JR, McKenzie RC, Beckett GJ (2003) Selenium in the immune system. J Nutr 133:1457S1459S.

4. Chen T, Wong YS, Zheng W, Bai Y, Huang L (2008) Selenium nanoparticles fabricated in Undaria pinnatifida polysaccharide solutions induce mitochondria-mediated apoptosis in A375 human melanoma cells. Colloids surface B 67:26-31.

5. Chen JS (2012) An original discovery: selenium deficiency and Keshan disease (an endemic heart disease). Asia Pac J Clin Nutr 21:320-326.

6. Eswayah AS, Smith TJ, Gardiner PH (2016) Microbial transformations of selenium species of relevance to bioremediation. Appl Environ Microbiol 82:4848-4859.

7. Fang J, Lu J, Holmgren A (2005) Thioredoxin reductase is irreversibly modified by curcumin a novel molecular mechanism for its anticancer activity. J Biol Chem 280: 25284-25290.

8. Forootanfar H, Adeli-Sardou M, Nikkhoo M, Mehrabani M, Amir-Heidari B, Shahverdi AR, Shakibaie M (2014) Antioxidant and cytotoxic effect of biologically synthesized selenium nanoparticles in comparison to selenium dioxide. J Trace Elem Med Bio 28:75-79.

9. Ghosh A, Chowdhury N, Chandra G (2012) Plant extracts as potential mosquito larvicides. IJMR 135:

10. Ghosh A, Mohod AM, Paknikar KM, Jain RKb (2008) Isolation and characterization of selenite-and selenate-tolerant microorganisms from selenium-contaminated sites. World J Microbiol Biotechnol24:1607-1611.

11. Higashi RM, Cassel TA, Skorupa JP, Fan TW (2005) Remediation and bioremediation of seleniumcontaminated waters. New York: Wiley Press.

12. Hunter WJ, Manter DK (2009) Reduction of selenite to elemental red selenium by Pseudomonas strain CA5. Curr Microbiol 58:493-498.

13. Javed S, Sarwar A, Tassawar M, Faisal M (2015) Conversion of selenite to elemental selenium by indigenous bacteria isolated from polluted areas. Chem Spec Bioavailab 27:162-168.

14. Kessi J, Ramuz M, Wehrli E, Spycher M, Bachofen R (1999) Reduction of selenite and detoxification of elemental selenium by the Phototrophic Bacterium Rhodospirillum rubrum. Appl Environ Microbiol 65:4734-4740.

15. Khanolkar DS, Dubey SK, Naik MM (2015) Biotransformation of tributyltin chloride to less toxic dibutyltin dichloridee and monobutyltin trichloride by Klebsiella pneumoniae strain SD9. Int Biodeter Biodegr104:212-218.

16. Kong L, Yuan Q, Zhu H, Li Y, Guo Q, Wang Q, Bi X, Gao X (2011) The suppression of prostate LNCaP cancer cells growth by Selenium nanoparticles through Akt/Mdm2/AR controlled apoptosis. Biomaterials32:6515-6522. 
17. Luo H, Wang F, Bai Y, Chen T, Zheng W (2012) Selenium nanoparticles inhibit the growth of HeLa and MDA-MB-231 cells through induction of S phase arrest. Colloid SurfB 94:304-308.

18. Mishra RR, Prajapati S, Das J, Dangar TK. Das N, Thatoi H (2011) Reduction of selenite to red elemental selenium by moderately halotolerant Bacillus megaterium strains isolated from Bhitarkanika mangrove soil and characterization of reduced product. Chemosphere 84:231-1237.

19. Morris J, Crane S (2013) Selenium toxicity from a misformulated dietary supplement, adverse health effects, and the temporal response in the nail biologic monitor. Nutrients 5:1024-1057.

20. Mujawar SY, Shamim K, Vaigankar DC, Dubey SK (2019) Arsenite biotransformation and bioaccumulation by Klebsiella pneumoniae strain SSSW7 possessing arsenite oxidase (aioA) gene. BioMetals 32:65-76.

21. Naik MM, Dubey SK (2017) Marine Pollution and Microbial Remediation. Springer.

22. Narasingarao P, Häggblom MM (2007). Identification of anaerobic selenate-respiring bacteria from aquatic sediments. Appl Environ Microbiol 73:3519-3527.

23. Niki E (2010). Assessment of antioxidant capacity in vitro and in vivo. Free Radic Biol Med 49:503515.

24. Oremland RS, Herbel MJ, Blum JS, Langley S, Beveridge TJ, Ajayan PM, Sutto T, Ellis AV, Curran S (2004). Structural and spectral features of selenium nanospheres produced by Se-respiring bacteria. Appl Environ Microbiol 70:52-60.

25. Ouédraogo O, Chételat J, Amyot M (2015) Bioaccumulation and trophic transfer of mercury and selenium in African sub-tropical fluvial reservoirs food webs (Burkina Faso). PLoS One 10: 0123048.

26. Presentato A, Piacenza E, Anikovskiy M, Cappelletti M, Zannoni D, Turner RJ (2018) Biosynthesis of selenium-nanoparticles and-nanorods as a product of selenite bioconversion by the aerobic bacterium Rhodococcus aetherivorans New Biotechnol 41:1-8.

27. Ramya S, Shanmugasundaram T, Balagurunathan R (2015) Biomedical potential of actinobacterially synthesized selenium nanoparticles with special reference to anti-biofilm, anti-oxidant, wound healing, cytotoxic and anti-viral activities. J Trace Elem Med Bio 32:30-39.

28. Ranjard L, Prigent-Combaret C, Nazaret S, Cournoyer B (2002) Methylation of inorganic and organic selenium by the bacterial thiopurine methyltransferase. J Bacteriol184:3146-3149.

29. Rathgeber C, Yurkova N, Stackebrandt E, Beatty JT, Yurkov V (2002) Isolation of tellurite-and seleniteresistant bacteria from hydrothermal vents of the Juan de Fuca Ridge in the Pacific Ocean. Appl Environ Microbiol 68:4613-4622.

30. Rauschenbach I, Narasingarao P, Häggblom MM (2011) Desulfurispirillum indicum nov., a selenateand selenite-respiring bacterium isolated from an estuarine canal. Int J Syst Evol Microbiol 61:654658.

31. Samant S, Naik M, Parulekar K, Charya L, Vaigankar D (2018) Selenium reducing Citrobacter fruendii strain KP6 from Mandovi estuary and its potential application in selenium nanoparticle synthesis. Proc Natl Sci IndiaSect B: Bio Sci 88:747-754. 
32. Seng HL, Tiekink ER (2012) Anti-cancer potential of selenium-and tellurium-containing species: opportunities abound! Appl Organomet Chem. 26:655-662.

33. Shakibaie M, Forootanfar H, Golkari Y, Mohammadi-Khorsand T, Shakibaie MR (2015) Anti-biofilm activity of biogenic selenium nanoparticles and selenium dioxide against clinical isolates of Staphylococcus aureus, Pseudomonas aeruginosa, and Proteus mirabilis. J Trace Elem Med Biol 29:235-241.

34. Shirsat S, Kadam A, Naushad M, Mane RS (2015) Selenium nanostructures: microbial synthesis and applications. Rsc Advances 5 :92799-92811.

35. Siddique T, Zhang Y, Okeke BC, Frankenberger Jr WT (2006) Characterization of sediment bacteria involved in selenium reduction. Bioresour Technol 97: 1041-1049.

36. Soda S, Takahashi H, Kagami T, Miyake M, Notaguchi E, Sei K, Iwasaki N, Ike M (2012) Biotreatment of selenium refinery wastewater using pilot-scale granular sludge and swim-bed bioreactors augmented with a selenium-reducing bacterium Pseudomonas stutzeri NT-I. Japan J Water Treatment Biol 48:63-71.

37. Sowndarya P, Ramkumar G, Shivakumar MS (2017) Green synthesis of selenium nanoparticles conjugated Clausena dentata plant leaf extract and their insecticidal potential against mosquito vectors. Artif Cell Nanomed B 451:490-1495.

38. Srivastava N, Mukhopadhyay M (2013) Biosynthesis and structural characterization of selenium nanoparticles mediated by Zooglea ramigera. Powder Technol 244:26-29.

39. Srivastava P, Braganca JM, Kowshik M (2014) In vivo synthesis of selenium nanoparticles by Halococcus salifodinae BK18 and their anti-proliferative properties against HeLa cell line. Biotechnol Prog 30:1480-1487.

40. Srivastava P, Kowshik M (2016) Anti-neoplastic selenium nanoparticles from Idiomarina PR588. Enzyme Microb Technol95:192-200.

41. Stoeva S, Klabunde KJ, Sorensen CM, Dragieva I (2002) Gram-scale synthesis of monodisperse gold colloids by the solvated metal atom dispersion method and digestive ripening and their organization into two-and three-dimensional structures. J Am Chem Soc 124:2305-2311.

42. Sunitha MSL, Prashanth S, Kishor PK (2015) Characterization of arsenic-resistant bacteria and their ars genotype for metal bioremediation. Int J Sci Eng Res 6:304-309.

43. Tamura K, Stecher G, Peterson D, Filipski A, Kumar S (2013) MEGA6: molecular evolutionary genetics analysis version 6.0. Mol Biol Evol 30:2725-2729.

44. Tan Y, Yao R, Wang R, Wang D, Wang G, Zheng S (2016) Reduction of selenite to Se (0) nanoparticles by filamentous bacterium Streptomyces ES2-5 isolated from a selenium mining soil. Microb Cell Fact 15:157.

45. Torres SK, Campos VL, León CG, Rodríguez-Llamazares SM, Rojas SM, Gonzalez M, Smith C, Mondaca MA (2012) Biosynthesis of selenium nanoparticles by Pantoea agglomerans and their antioxidant activity. J Nanoparticle Res 14:1236. 
46. Turlo J, Gutkowska B, Herold F (2010) Effect of selenium enrichment on antioxidant activities and chemical composition of Lentinula edodes (Berk.) Pegl. mycelial extracts. Food Chem Toxicol 48:1085-1091.

47. Vaigankar DC, Dubey SK, Mujawar SY, D'Costa A, Shyama SK (2018) Tellurite biotransformation and detoxification by Shewanella baltica with simultaneous synthesis of tellurium nanorods exhibiting photo-catalytic and anti-biofilm activity. Ecotox Environ Safe 165:516-526.

48. Velmurugan P, Lee SM, Cho M, Park JH, Seo SK, Myung H, Bang KS, Oh BT (2014) Antibacterial activity of silver nanoparticle-coated fabric and leather against odor and skin infection causing bacteria. Appl Microbiol Biotechnol 98(19):8179-89.

49. Watkinson JH (1966) Fluorimetric determination of selenium in bio- logical material with 2, 3diaminonaphtalene. Anal Chem 38:92-97.

50. Yang YC, Lee SG, Lee HK, Kim MK, Lee SH, Lee HS (2002) A piperidine amide extracted from Piper longum fruit shows activity against Aedes aegypti mosquito larvae. J Agric Food Chem 50:37653767.

51. Zeng H, Combs Jr G (2008). Selenium as an anticancer nutrient: roles in cell proliferation and tumor cell invasion. J Nutr Biochem 19: 1-7.

52. Zhang J, Wang X, Xu T (2007) Elemental selenium at nano size (Nano-Se) as a potential chemopreventive agent with reduced risk of selenium toxicity: comparison with semethylselenocysteine in mice. Toxicol Sci 101:22-31.

53. Zheng JS, Zheng SY, Zhang YB, Yu B, Zheng W, Yang F, Chen T (2011) Sialic acid surface decoration enhances cellular uptake and apoptosis-inducing activity of selenium nanoparticles. Colloids Surf B 83:183-187.

\section{Figures}




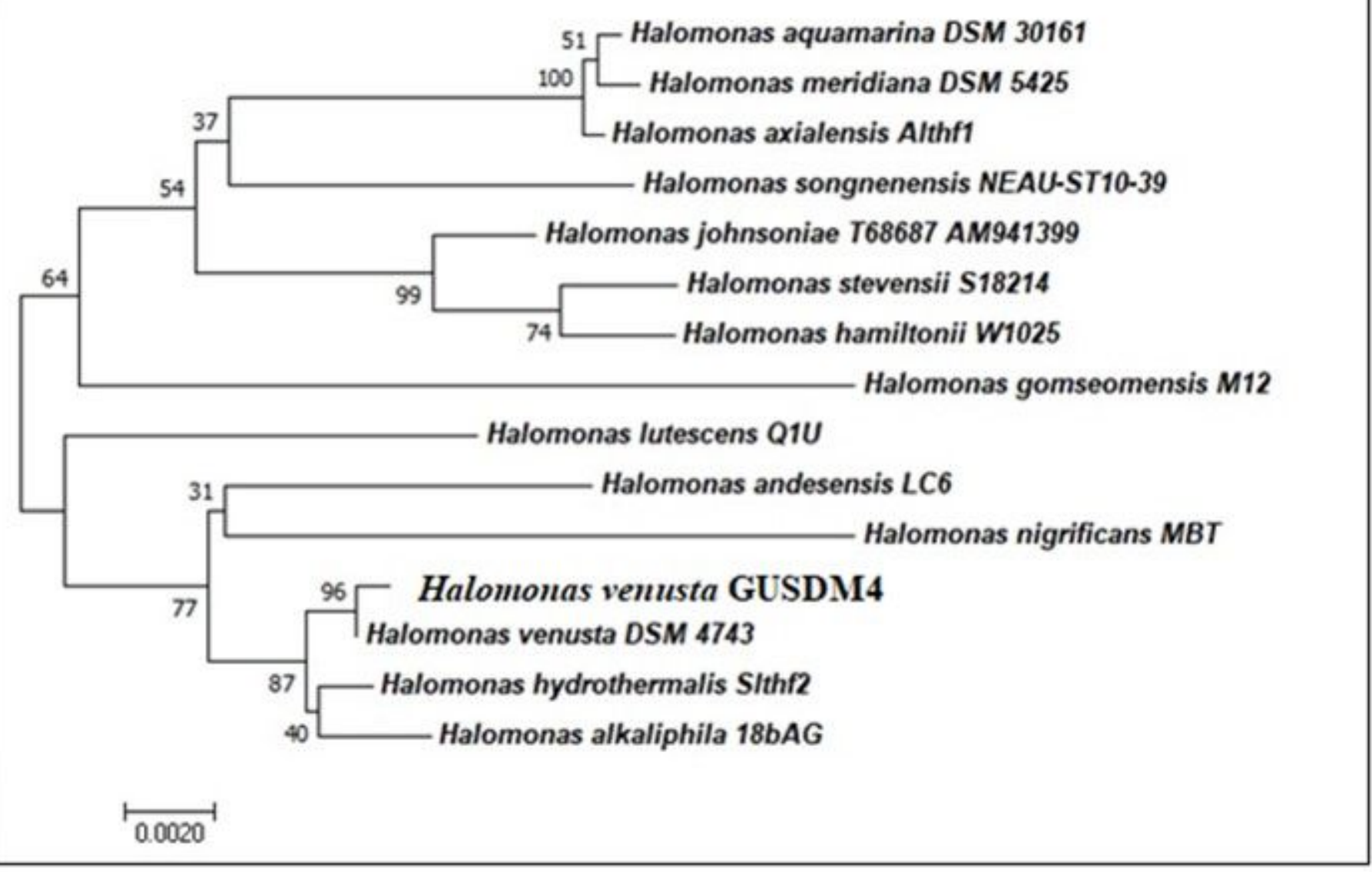

Figure 1

Phylogenetic relatedness of Halomonas venusta strain GUSDM4 with other Halomonas spp. (Bootstrap values include 1000 replicates).
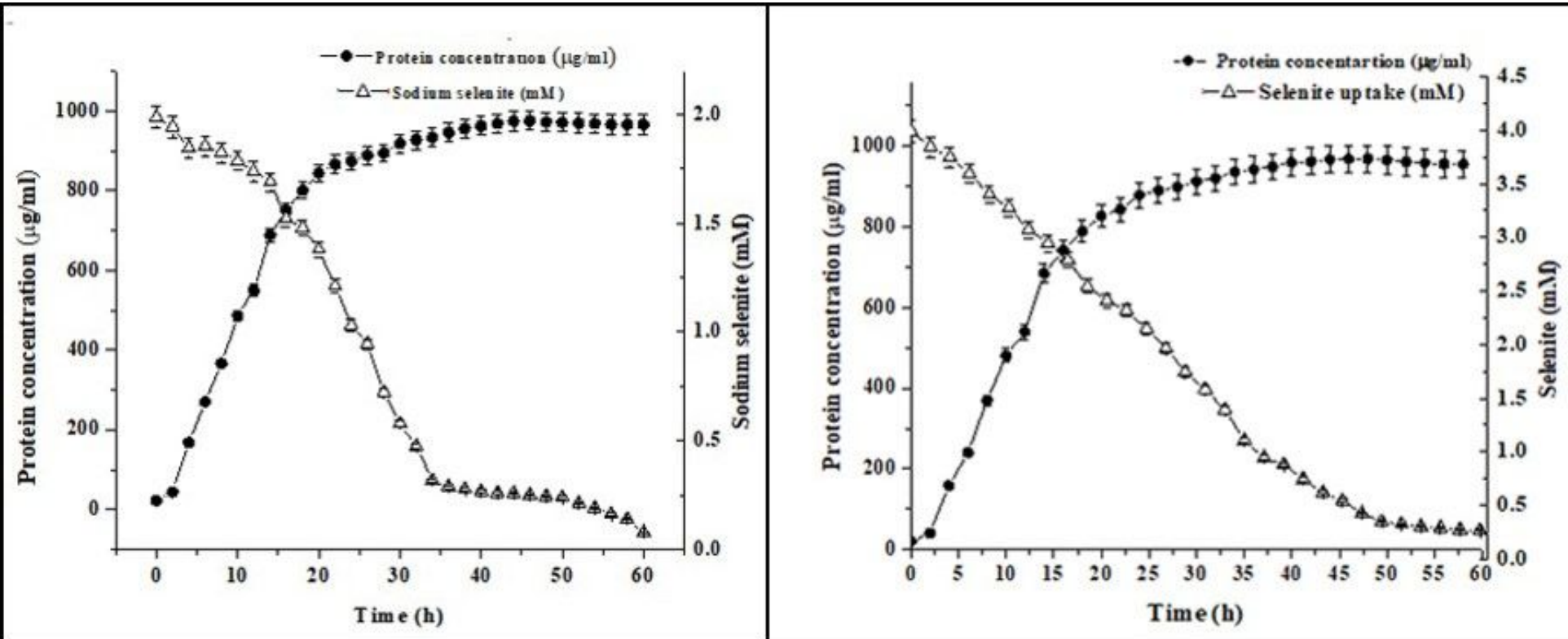

Figure 2 
Growth pattern and selenite uptake by strain GUSDM4 in the presence of $2 \mathrm{mM}$ and $4 \mathrm{mM} \mathrm{Na} 2 \mathrm{SeO} 3$.
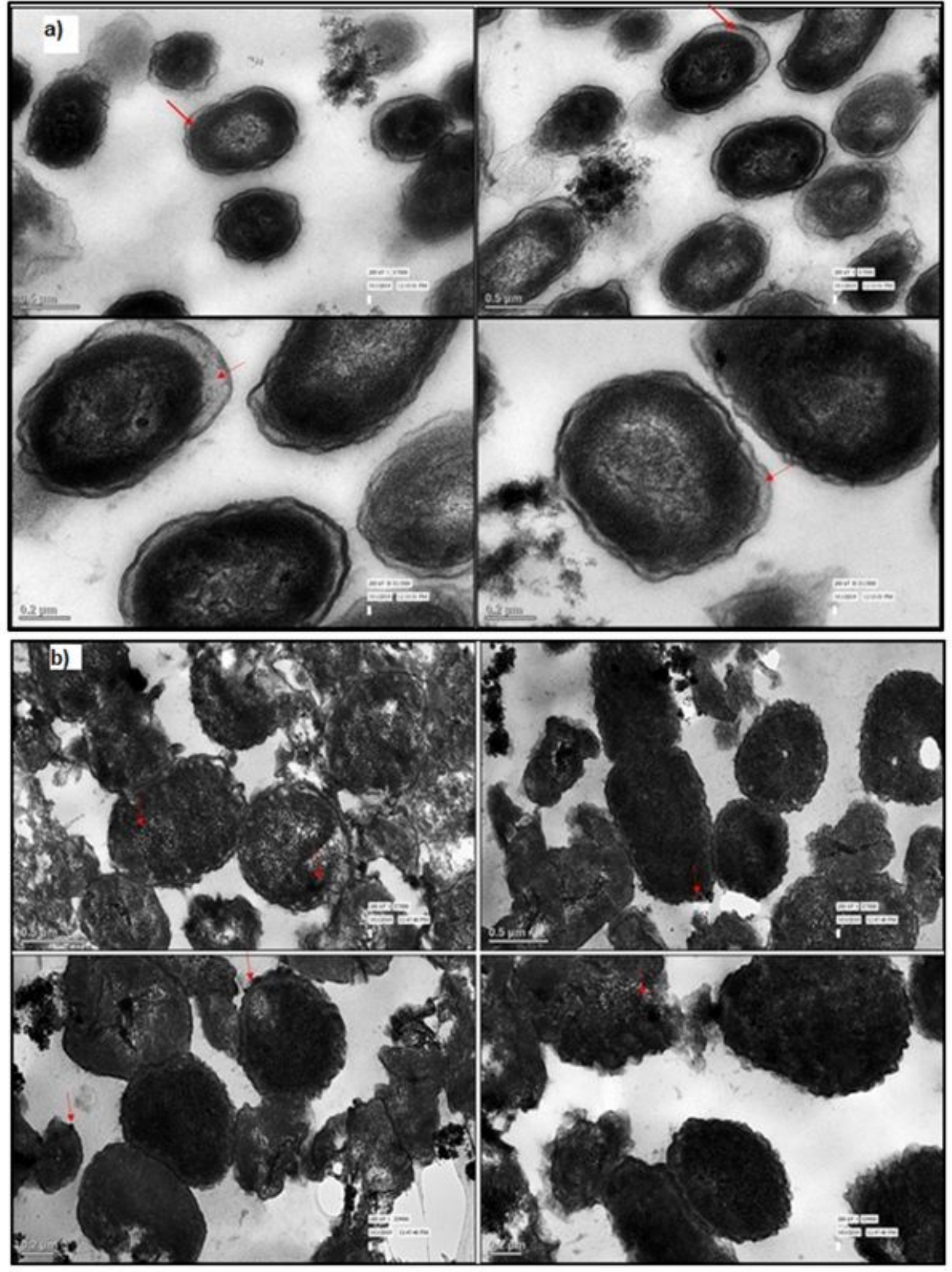

Figure 3

Transmission electron micrographs of cells of Halomonas venusta strain GUSDM4: Bacterial cells without sodium selenite exposure showing clear periplasm (magnification from left: 7000X, 7000X, 15000X and 15000X) a); Bacterial cells exposed to $4 \mathrm{mM} \mathrm{Na2SeO3} \mathrm{showing} \mathrm{periplasm} \mathrm{with} \mathrm{dark}$ 
granules of SeNPs. Red arrows indicate localization of Se nanospheres (Magnification from left: $7000 \mathrm{X}$, 7000X, 9900X and 9900X) b).

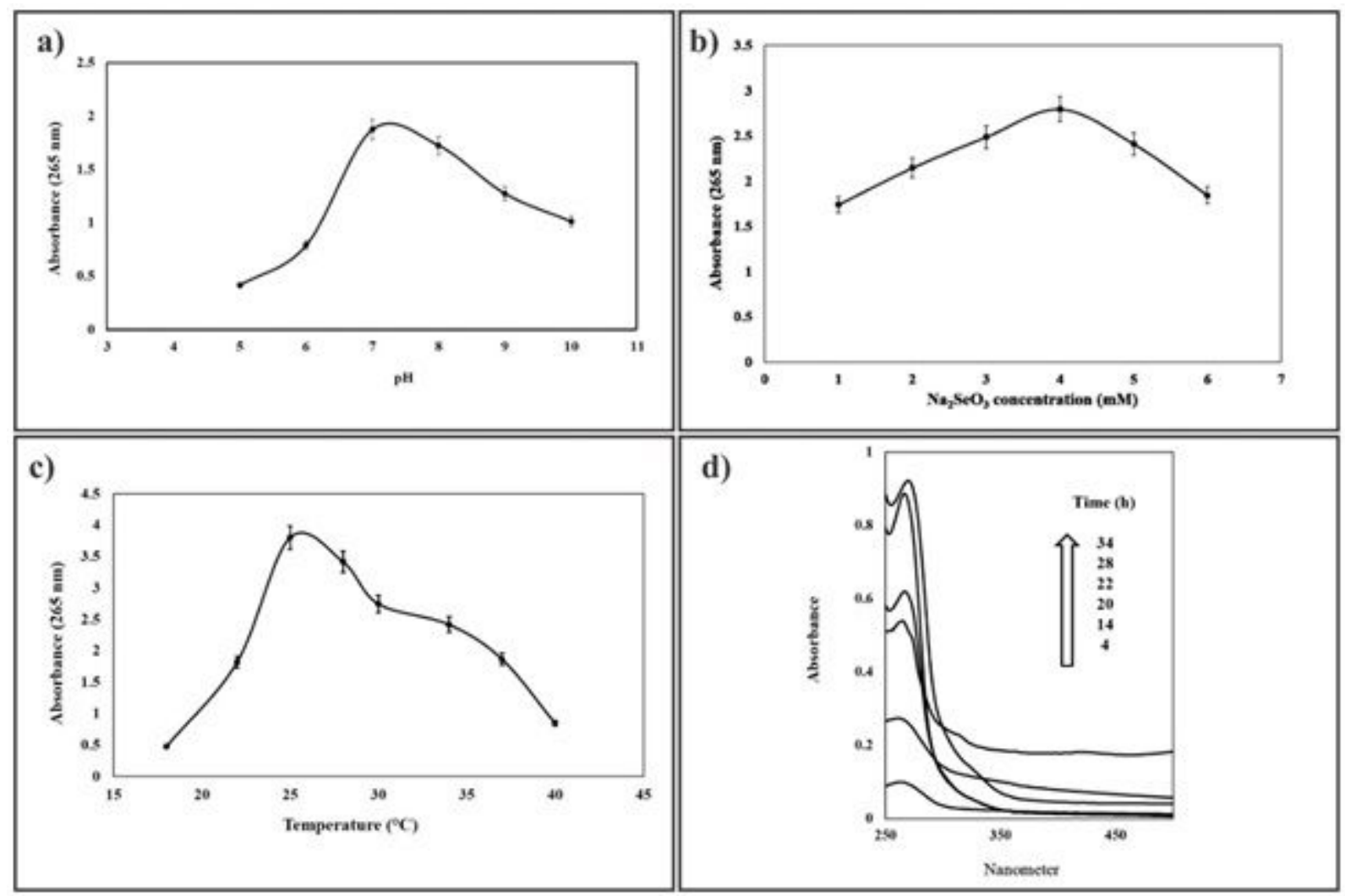

Figure 4

Biosynthesis of SeNPs at: different $\mathrm{pH}$ a), different $\mathrm{Na} 2 \mathrm{SeO} 3$ concentration b), different temperature c), time course study of SeNPs biosynthesis under optimized conditions d). 


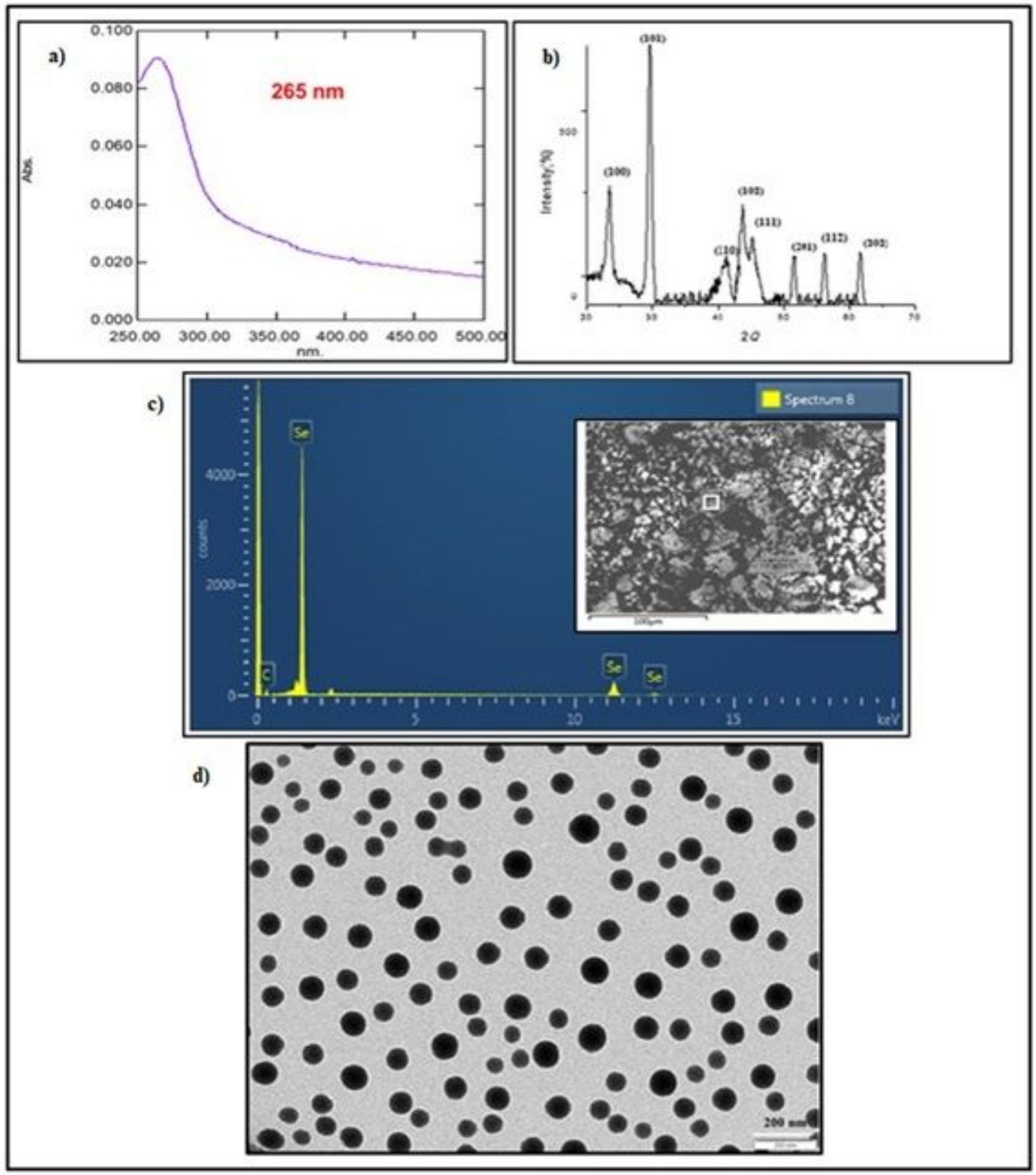

Figure 5

Characterization of biogenic SeNPs: Absorbance maxima for biosynthesized SeNPs at $265 \mathrm{~nm}$ a), XRD pattern for biosynthesized SeNPs exhibiting characteristics Bragg's peaks b), EDAX spectrum exhibiting characteristic peaks of elemental Se c), TEM micrograph of biogenic SeNPs d). 


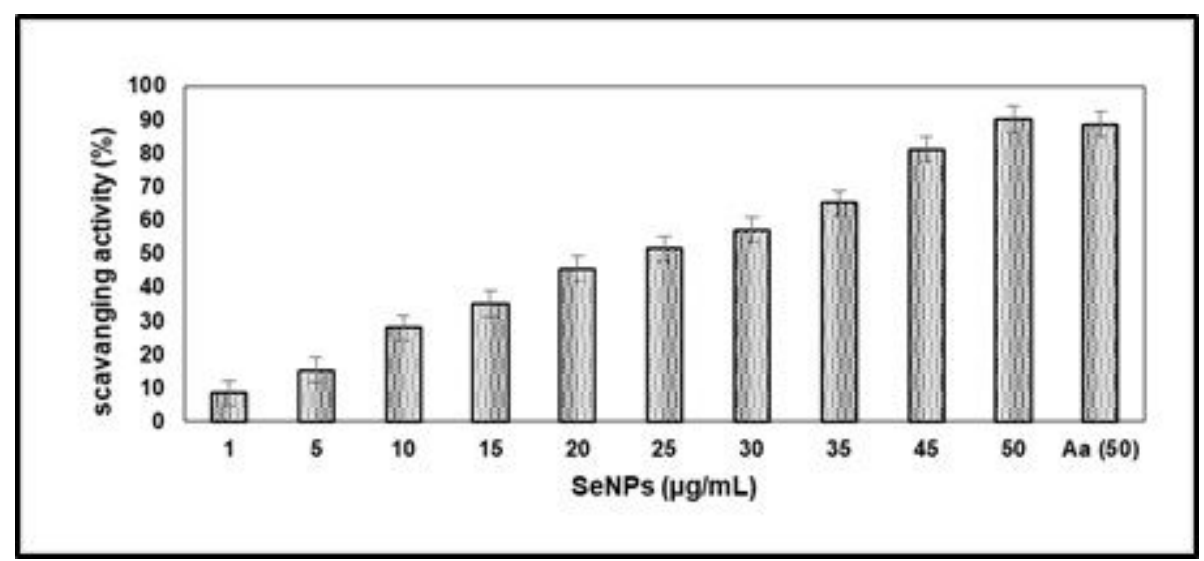

Figure 6

Free radical scavenging activity of biogenic SeNPs. Ascorbic acid (Aa) served as a standard. 

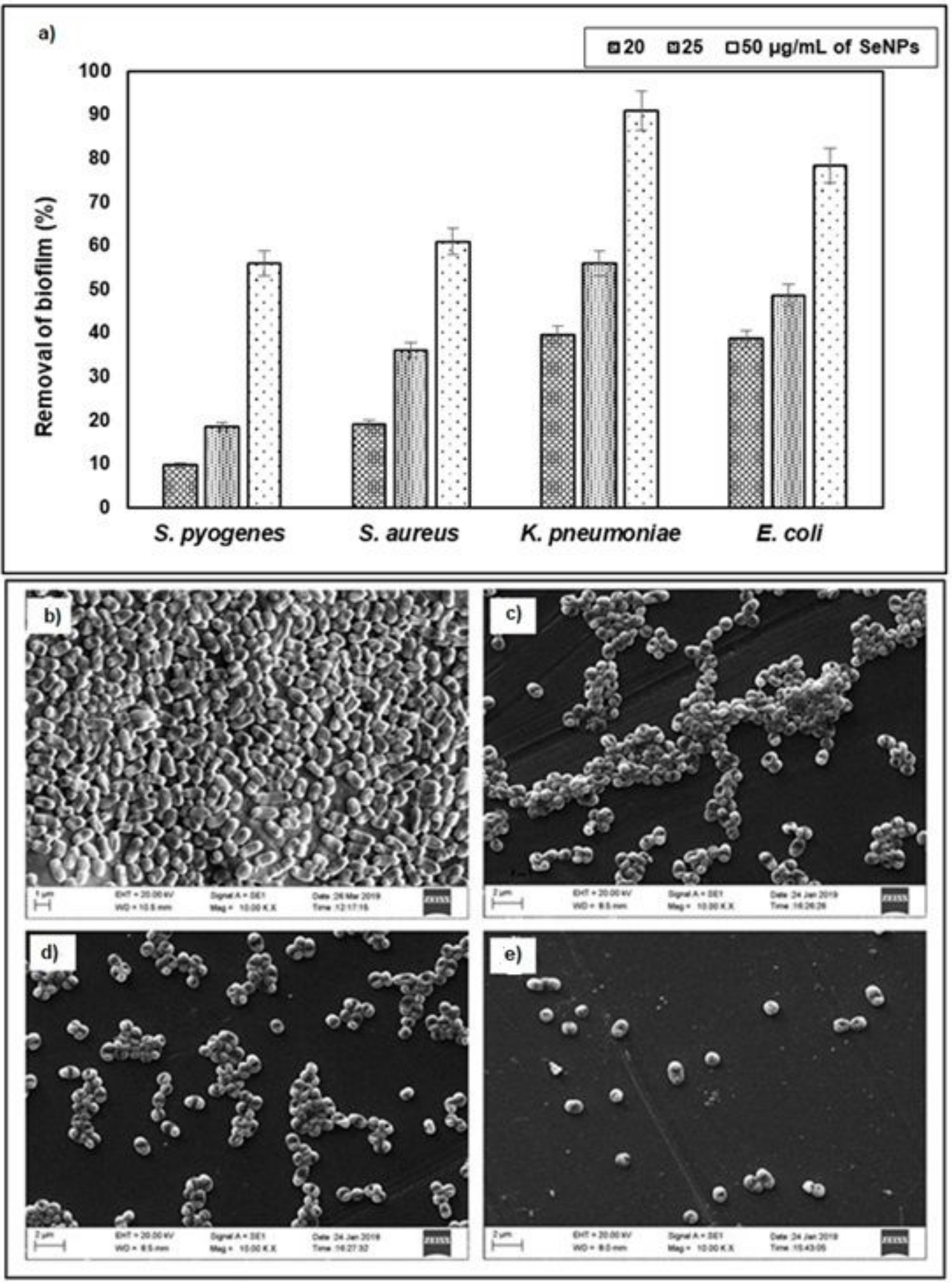

Figure 7

$\%$ Anti-biofilm activity of SeNPs against human bacterial pathogens a), SEM images of human pathogens at various SeNPs concentrations: $0 \mu \mathrm{g} / \mathrm{mL}$ b), $20 \mu \mathrm{g} / \mathrm{mL}$ c), $25 \mu \mathrm{g} / \mathrm{mL} \mathrm{d}), 50 \mu \mathrm{g} / \mathrm{mL}$ e). 


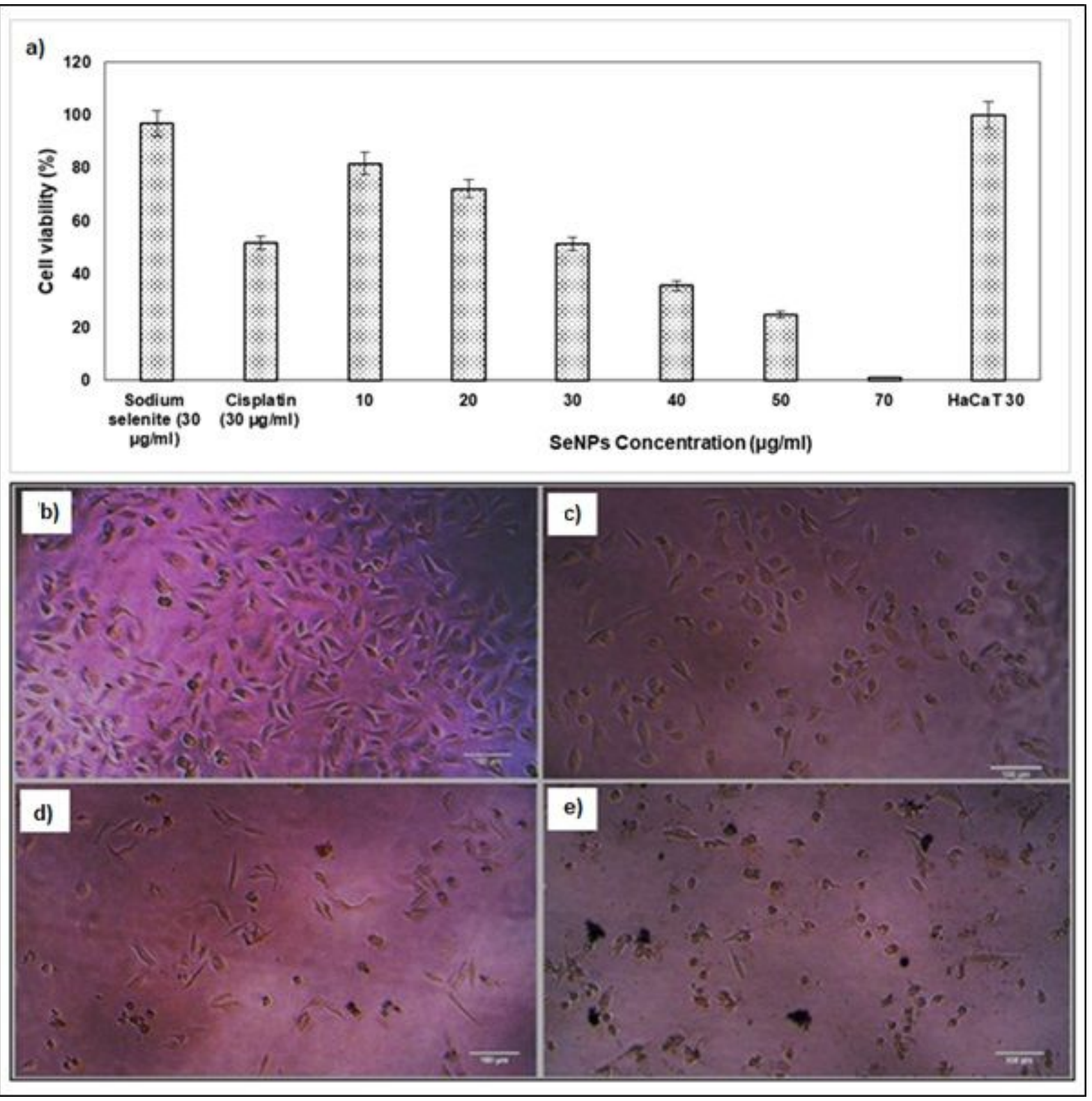

\section{Figure 8}

Dose dependent anti-proliferative activity of biogenic SeNPs a), Microscopic images of A549 cells: control cells without NPs treatment b), Cells treated with $30 \mu \mathrm{g} / \mathrm{mL}$ of cisplatin c), Cells treated with 30 $\mu \mathrm{g} / \mathrm{L}$ SeNPs d), Cells treated with $70 \mu \mathrm{g} / \mathrm{mL}$ SeNPs e).

\section{Supplementary Files}

This is a list of supplementary files associated with this preprint. Click to download.

- Graph.abs..jpg

- supp.figsSE.docx 